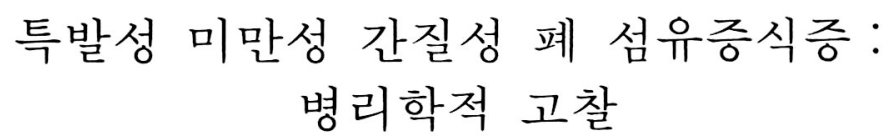

한양대학교 의과대학 병리학교실

이 중 달

\title{
Idiopathic Diffuse Interstitial Fibrosis of Lung: Pathologic Approach
}

Jung Dal Lee, M.D.

Department of Pathology, College of Medicine, Hanyang University, Seoul, Korea

미만성 간질성 폐질환(diffuse interstitial pulmonary disease) 은 병리학적 및 임상적 소견을 공통으로 하는 여러 이질적인 폐질환에 대한 포괄적인 명칭이다. 이런 질환군은 병태생리학적으로 제한성 폐질환(restrictive pulmonary disease), 또는 방사선학적으로 침윤성 폐 질환(infiltrative lung disease) 등으로 불리고 있다. 이러한 명칭들은 이 질환들의 본태를 설명하는데 적절한 표현은 아니지만, 각 명칭이 내포하고 있는 뜻은 이 질 환들의 병리학적 및 생리학적 특징을 어느 정도 반영하 고 있다.

미만성 간질성 폐질환을 유발할 수 있는 원인으로써 현재 100 가지 이상의 화학적, 물리적 및 생물학적 인자 를 열거하고 있다. 이러한 인자는 날이 갈수록 더 추가 되는 추세이다. 실로 이 질환군에는 150 내지 200 이상의 서로 상이한 질병 단위가 포함되지만, 서로 상이한 원인 이 동일한 병변을 유발할 수 있고, 이와 반대로 동일한 원인이 상이한 병리학적 변화를 초래하기도 한다. 또한 미만성 간질성 폐질환의 $2 / 3$ 예 이상에서 원인 인자를 찾 지 못하는 특발성 간질성 폐 섬유증식증 (idiopathic interstitial pulmonary fibrosis, IDF)에 속함으로, 이들의 원인적 분류가 실제적으로 불가능하다. 따라서 많은 경 우 폐의 생검 소견에 의한 형태학적 변화에 근거한 분류 를 시도하고 있는 형편이다.

미만성 간질성 폐 질환에 포함되는 소수의 특이한 질 환들만이 임상적으로나 형태학적으로 뚜렷한 IDF의 소 견을 발현하고 이들의 공통적인 병리학적 변화는 하부

\section{용어 및 약어}

idiopathic (diffuse) interstitial pulmonary fibrosis, IDF : 특발성(미만성) 간질성 폐 섬유증식증 lower respiratory airway (tract), LRA : 하부호홉기도 respiratory bronchiole, $\mathrm{RB}$ : 호홉성 세기관지 effector cell : 작동 (주효) 세포 alveolar macrophage, $\mathrm{Ma}$ : 폐포 대식세포 terininal bronchiole, TB : 종말 세기관지 pneumocyte, Pn: 폐포(상피) 세포

neutrophilic chemotactic factor: 호중구 추화성인자 cryptogenic fibrosing alveolitis : 특발성 섬유화성 폐포염 desquamative interstitial pneumonia. DIP : 탈락성 간질 성 폐렴

usual interstitial pneumonia, UIP: 상투성 간질성 폐렴 diffuse alveolar damage, DAD : 미만성 폐포 손상 bronchioloalveolar lavage, $\mathrm{BAL}$ : 세기관지 폐포세척

호흡기도(LRA)를 파괴하고 폐포-모세혈관 단위의 손 실을 가져와서 가스 교환에 장애를 초래하게 된다.

임상증상으로, 점점 심하여지는 호흡곤란이 수일 내 지 수주 사이에 급격히 발현하는 경우도 있지만, 대다수 예어서는 수개월 내지 수년에 걸쳐 증상이 점진적으로 악화한다. 비록 이러한 만성적인 간질성 폐질환의 원인 은 많은 경우 알 수 없으나 병리학적 변화의 발생과정은 잘 알려져 있다. 발병 과정에서 가장 초석적인 변화가 바 로 폐포염 (alveolitis)이라고 할 수 있다. 폐포염에 속발 하는 섬유 증식이 폐포-모세혈관 단위의 파괴를 초래하 
고 일련의 임상증상을 유발하게 되는 것이 이 질환의 특 징인 것이다.

이 병리학적 고찰에서는 원인 불명의 IDF의 발병 기 전과 병리학적 변화의 진전상태를 검토하고자 한다. 이 원고의 일부 내용은 이미 지난 결핵 및 호흡기학회 춘계 학술대회 석상에서 발표된 바 있다.

\section{하부 기도의 정상구조}

하부 기도는 호흡 기도의 말초 단위인 호흡성 세기관 지 $(\mathrm{RB})$ 와 그 원위부에 위치한 폐포관 및 폐포를 총괄하 는 구조를 뜻한다. 폐포염이 정상 폐구조를 파괴하는 기 전을 이해하기 위하여 폐포벽 (폐장의 간질)의 정상 구성 성분인 염증세포, 실질세포 및 기질을 검토할 필요가 있 다.

\section{1. 하부기도의 염증세포}

정상 폐장에 한 폐포당 약 80 개의 작동(주효)세포 (effector cell) 가 존재한다. 이 세포들은 폐포의 간질내 그리고 폐포의 상피 표면에 존재한다. 이들의 $90 \%$ 이상 이 폐포 대식세포 (alveolar macrophage, Ma)인데, 수 개월 내지 수년간 생존할 수 있다. 정상 폐장내에서 $\mathrm{Ma}$ 가 분할 증식할 수 있지만, 대다수의 대식 세포들은 폐 포내로 유주한 순환혈액의 단구들이다.

$\mathrm{Ma}$ 의 정상적인 역할중 하나는 흡입된 미생물과 먼지 를 제거하는 일이다. 그들은 정상적으로 포면 수용체 $\left(\mathrm{C}_{3 \mathrm{~b}}\right.$ 보체와 $\mathrm{IgG}$ 의 $\mathrm{Fc}$ 부위에 대한 수용체)를 이용하여 이 기능을 수행하게 된다. 또한, $\mathrm{Ma}$ 는 opson화 되지 않 은 입자들을 탐식할 수 있다. 건강한 개체에서는 $\mathrm{Ma}$ 가 활동을 하지 않고 있지만, 활성화되면 그들은 염증성 과 정과 면역 과정에 관여하는 많은 중재물(mediator)을 방출한다.

정상 폐장에서 림프구가 작동세포의 나머지 $10 \%$ 를 차 지한다. 대체적으로 폐장에 존개하는 림프구의 종류는 헐액내 분포와 비슷하나 폐장에는 $\mathrm{B}$ 세포가 약간 적고, $\mathrm{T}$ 세포의 수가 비교적 많다. 정상 폐장내에 존재하는 대 다수의 $\mathrm{T}$ 와 $\mathrm{B}$ 세포들은 활성화 되지 않은 상태이다.

$\mathrm{Ma}$ 와 림프구의 분포에 비하여 다형핵 백혈구는 대단 히 낮은 비율 ( $1 \%$ 미만)로 존재한다.

면역 globulin, 주로 $\operatorname{IgG}$ 와 $\operatorname{IgA}$ 가 정 상 개체의 폐포 상푀들 덮고 있는 횽액내에 존재한다. 대누분의 보제계
통이 역시 존재하지만, $\mathrm{C}_{5}$ 의 농도는 매우 낮다. 그래서 classical 및 alternative pathway의 초기 단계에 관여 하는 보체들이 LRA에 존재하고, 활성화될 수 있지만, 폐포내 $\mathrm{C}_{5}$ 의 양이 증가하지 않은한(예, 혈장으로부터의 유출) 기능적으로 충분한 양의 $\mathrm{C}_{5 \mathrm{a}}$ 가 형성되지 아니한 다.

\section{2. 폐포벽의 실질세포와 기질}

정상 성인 폐장은 $300 \times 10^{6}$ 의 폐포를 가진다. 이들은 종말 세기관지 (TB) 로부터 분지되어 입체적으로는 포도 송이 같고, 단면에서는 벌집처럼 보인다(Fig. 1).

전형적인 폐포는 200 300 $\mu \mathrm{m}$ 의 내경과 5 $10 \mu \mathrm{m}$ 두 께의 폐포벽을 가진다. 폐포벽은 단층의 상피세포(폐포 세포, pneumocyte, $\mathrm{Pn}$ ) 가 기저막을 덮고 있다. 기저막 은 얇고 연속적인 구조물로 제 IV형의 교원(collagen)인

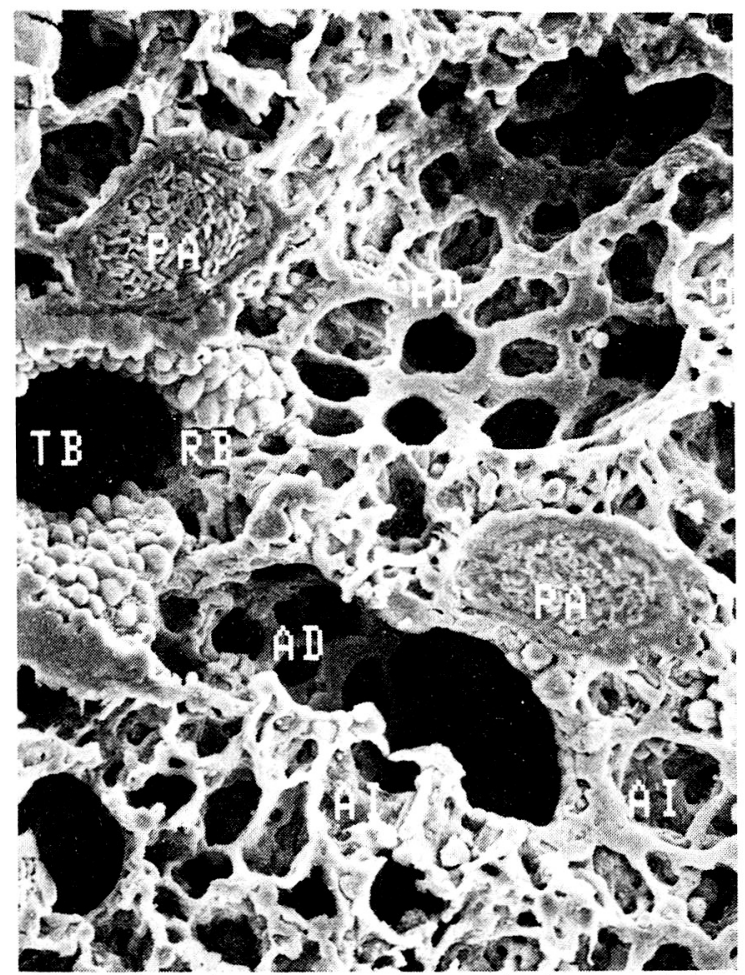

Fig. 1. Scanning electron microscopic feature of the normal lower respiratory airway. Alveolar ducts (AD) with many alveoli (A1) have a honeycomb appearance. Alveoli contain macrophages with ruffled surface. The terminal bronchiole is studded with Clara cells (SEN, X168,000).

(송북대 희대 멍러학표실 채종민 교수 제공). 
laminin을 함유한다. Laminin은 $\mathrm{Pn}$ 을 제 IV형 교원에 부착시키는 매체인 glycoprotein으로 구성된다. 그외에 proteoglycan같은 고분자 물질을 포함한다.

$\mathrm{Pn}$ 의 약 $1 / 3$ 은 제 I 형 세포(막상 폐포세포, membranous pneumocyte) 인데 판케이크 같은 납작한 세포로서 폐포 상피표면의 $90 \%$ 이상을 이 세포가 덮고 있다. 나머지는 제II형 세포(과립상 폐포세포, granular pneumocyte) 로서 주사위 모양을 하고 폐포 의 허탈을 방지하는 표면활성 물질을 분비한다.

폐장의 모세혈관은 여러 방향으로 가지를 뻗어 거물 모양으로 폐포벽내를 누비고 있다. 모세혈관의 내강은 연속적인 기저막위를 한층의 내피세포가 덮게된다. 비 록 내피와 상피의 기저막이 뚜렷하게 분리된 구조이지 만, 모세혈관이 폐포 내강과 가장 인접한 부위에서는 서 로 융합하고 있는데, 이 부위가 가스 교환이 활발히 진 행되는 부위가 된다.

상피와 내피의 기저막이 폐포 간질의 경계를 이루게 된다. 이 양 기저막 사이에 섬유모세포(fibroblast)와 결합조직의 기질이 존재하는데, 이 양구조물이 폐포벽 을 구성하는 조직양의 거의 $50 \%$ 에 달한다. 정상 폐장에 서 섬유모세포는 모든 실질 세포의 $37 \%$ 를 차지하며, 간 질양의 약 $2 / 3$ 을 점유한다. 가장 풍부한 간질성 기질 성 분은 제 I 형과 제 III형의 교원이다. 이들은 고분자 물 질로서 정상적으로 $2: 1$ 의 비율고 존재한다. 제 I 형 교 원의 대부분을 구성하는 원섬유(fibril)는 굵고, 고도의 신장력을 가지는 반면, 제 III형 교원에 풍부한 원섬유는 얇고 유연하다. 이런 교원과 더불어 간질성 기질은 elastin(폐포의 탄력성 수축을 관장하는 신장력이 강한 고분자 물질), proteoglycan 그리고 fibronectin등을 함유한다. Fibronectin은 섬유모세포가 교원 또는 다른 기질 성분에 유착할 수 있게하는 세포 표면 단백이다. 섬 유모세포와 간질성 기질이 폐포의 구조적인 윤곽을 유지 하는데 중요한 역할을 한다.

\section{손상과 섬유증식에 대한 일반적 개념}

IDF 초기에 관찰되는 폐포염은 폐포구조의 경한 변화 를 유발한다. 폐포벽의 전형적인 변화는 다수의 작동세 포와 부종으로 인한 간질의 팽창으로 이루어진다. 병변 이 진행함에 따라 폐포벽.의 모든 구성 성분에 현저한 변 화가 발생하게 된다. 초기의 제 I 형 $\mathrm{Pn}$ 과 모세혈관 내
피세포의 손실에 뒤이어 제 II 형 Pn과 간질의 섬유모세 포가 증식하게 되고, 제 I 형 교원의 축적이 뒤따르게 된

\section{1. 손상에 대한 폐포구조의 감수성}

$\mathrm{IDF}$ 는 제 I 형 $\mathrm{Pn}$ 과 폐포 모세혈관의 손실을 초기 변 화로 한다. 왜냐하면, 제 I 형 $\mathrm{Pn}$ 과 내피세포들은 손상 에 대하여 매우 감수성이 높기 때문이다. 이와 반대로 제 II 형 Pn과 간질 섬유모세포들은 비교적 저항성이 높다. 이와 대조적으로 간질성 기질과 가저막의 결합조직 성분 은 비교적 견고한 고분자 구성물로서 소수의 효소에 의 해서만 분해된다. 다만 몇개의 단백 분해 효소만이 제 I 형과 제 III형의 교월을 파괴할 수 있고, 다른 단백 분해 효소들은 기저막 구성물인 제 IV형 교원과 laminin을 분 해한다.

IDF에 관여하는 모든 염증세포들 중에서 호중구가 손 상을 유발하는 가장 강한 능력을 가진다. 활성화된 호중 구는 폐장의 모든 실질세포에 대하여 독성이 강한데, 그 이유는 이 세포가 고도의 반응성 산소 대사물 (oxidant) 을 방출하기 때문으로 생각된다. 더욱더, 호중구는 결합 조직의 강력한 단백 분해 효소를 운반하는데, 제 I 형 교 원을 분해할 수 있는 교원섬유 분해 효소(collagenase) 와 폐포벽의 결합조직 구성물을 분해할 수 있는 탄력 섬 유 분해 효소(elastase)를 가진다. 그런고로 다수의 호 중구가 관여하는 만성 폐포염은 폐포구조의 심한 파괴를 동반하게 된다.

\section{2. 폐포 구조의 수복}

비록 폐포-모세혈관 단위의 완전한 재생이 가능한 것 은 아니지만, LRA의 실질세포들은 폐포벽의 손상된 구 성분을 수복하는데 제한된 능력을 가진다. 제 I 형 $\mathrm{Pn}$ 는 증식할 수 없지만, 제 II 형 $\mathrm{Pn}$ 은 증식할 수 있고, 증 식한 세 II형 $\mathrm{Pn}$ 이 제 I 형 $\mathrm{Pn}$ 으로 분화한다. 손상이 심 하고 만성적일 경우에는 마치 호중구에 의하여 지배되는 지속적인 폐포염때처럼 제 I 형 $\mathrm{Pn}$ 는 괴사에 빠지고, 상 피표면은 제 II형 $\mathrm{Pn}$ 에 의하여 거의 전부 대치된다. 이 때에 $\mathrm{RB}$ 로부터 이주해서 내려온 입방세포도 관여한다. $\mathrm{Pn}$ 의 재분포는 건강한 기저막이 존재함으로써 이루어진 다. 만일 기저막이 결손되면, 상피세포는 이주할 수 있 는 표면을 갖지 못하고, 재생해야할 부위가 파괴되어 $\mathrm{Pn}$ 의 재분포가 불가능하게 된다. 


\section{3. 폐포벽의 섬유증식}

폐포의 실질세포에 강한 손상이 가하여져서, 폐포의 구조가 정상으로 회복할 수 잆게 되면, 섬유증식이 속발 한다. 폐포벽의 섬유화는 모세혈관과 같은 섬세한 구조 를 잠식함으로써 폐포-모세혈관 기능 부전이 초래된 다.

폐포벽의 섬유화는 폐포간질의 증가로 나타나는데, 섬유모세포의 숫적 증가와 섬유모세포의 생성물인 제 I 형 교원의 양적 증가를 동반하게 된다. 폐포벽내 제 I 형 교원의 축적은 폐포내 여러 실질세포의 상대적인 비 율의 변화를 초래한다. 가장 기본적인 변화는 섬유모세 포의 현저한 수적 증가이다. 섬유모세포가 LRA에서 제 I 형 교원의 중요한 생산자이기 때문에(섬유모세포가 생산하는 교원의 80 90\%가 제 I 형 교원이다), 섬유모 세포의 비교적 증가는 간질성 기질에 있는 제 I 형 교원 의 양적 증가를 초래하게 된다.

$\mathrm{Ma}$ 가 적절하게 활성화되면, 간질성 섬유모세포의 국 소적 증가와 증식을 유발하게 된다. 간질성 폐 질환 환 자의 $\mathrm{Ma}$ 는 fibronectin을 다량 방출하는데, fibronectin은 섬유모세포에 대하여 추화성이 있고, 기질 성 분에 섬유모세포를 유착시키며, 증식에 필요한 신호를 섬유모세포에 보낸다. 또한, 이러한 환자의 $\mathrm{Ma}$ 는 폐포 대식세포 기원성 성장 인자를 자발적으로 방출하며, 섬 유모세포로 하여금 insulin양 성장 인자의 방출을 유도 하고, 이것이 인접한 섬유모세포를 증식케하는 신호를 보낸다.

비록 손상과 섬유화 과정은 다른 중재물에 의하여 진 행되지만. 폐포벽의 이러한 형태학적 변화는 서로 밀접 하게 연관되어 발생한다. 일반적으로 강력한 손상은 광 범위한 섬유화를 동반한다. 다수의 호중구를 특징으로 하는 폐포염에서는 다수의 림프구와 소수의 호중구가 관 여하는 폐포염에서 보다 더 광범위한 손상과 섬유증식이 발생한다.

\section{폐포염의 일반적 특징}

간질성 폐 질환때 손상과 섬유증식을 유발하는 폐포염 의 역할을 이해하기 위하여, 염증의 본질적인 측면을 생 각하는 것이 중요하다. 즉, 출현하는 작동세포의 수, 작 동세포의 종류 그리고 인들의 활성한 상태이다. 엽증의
이러한 소견의 총합이 바로 간질성 폐 질환에 나타나는 폐포 구조의 파괴 형태와 파괴 범위를 결정하는 요소가 되는 것이다.

\section{1. 작동세포의 수}

활동성인 IDF에서는 폐포벽의 작동세포 수가 현저하 게 증가한다. 이러한 증가는 작동세포의 국소적인 증식 과 말초 혈류로부터의 보충으로 이루어 진다.

\section{2. 작동세포의 종류}

IDF에서 폐포염의 가장 특징적인 소견은 작동세포의 구성 비율의 현저한 변화이다. 또한, 간질성 폐 질환의 종류에 따라 작동세포의 비율이 매우 특이하게 변화한 다. 예를들면, 활동성 $\mathrm{IDF}$ 때 폐포염의 작동세포들은 주 로 호중구와 대식세포에 의하여 지배되고, 소수의 호산 구와 림프구가 관여하는 반면, 활동성인 sarcoidosis에 서는 $\mathrm{T}$ 림프구와 대식세포가 주역을 하고, 소수의 호중 구와 호산구가 관여한다. LRA의 이러한 형태학적 변화 는 말초 혈액의 변화와 평행하지 않는다. 호중구가 활동 성 IDF에 동반된 폐포염의 주된 구성 세포이지만, 혈액 내 호중구의 수는 대개 증가하지 않는다. 그래서 이러한 질환들에 동반된 폐포염을 정확히 평가하기 위하여 $\mathrm{LRA}$ 의 국소적인 염증세포를 평가하는 것이 중요하다.

\section{3. 작동세포의 활성}

폐포염을 일으키는 염증세포의 수와 구성 비율의 변화 뿐만 아니라, 그들의 활성상태가 또한 여러 가질성 폐 질 환들을 특징지어 준다. 비록 $\mathrm{Ma}$ 가 폐포 구조를 파괴할 수 있는 여러 중재물을 방출하는 능력을 가지지만, 외부 자극에 의하여 활성화 될때만이 이 능력을 발휘할 수 있 다. 즉, 많은 수의 비활성 작동세포가 중요한 것이 아니 라, 같은 수일지라도 중재물을 방출하는 세포가 더욱 중 요한 것이다. 더욱더 손상의 성상은 방출되는 중재물의 특이한 종류에 따라 다르다. 예를들면, $\mathrm{Ma}$ 는 호중구 추 화성 인자를 방출할 수 있는데 이 중재물은 산화효소와 단백 분해효소로 강력하게 무장된 호중구를 끌어 당길 수 있는 능력을 가진다(Fig. 2). 


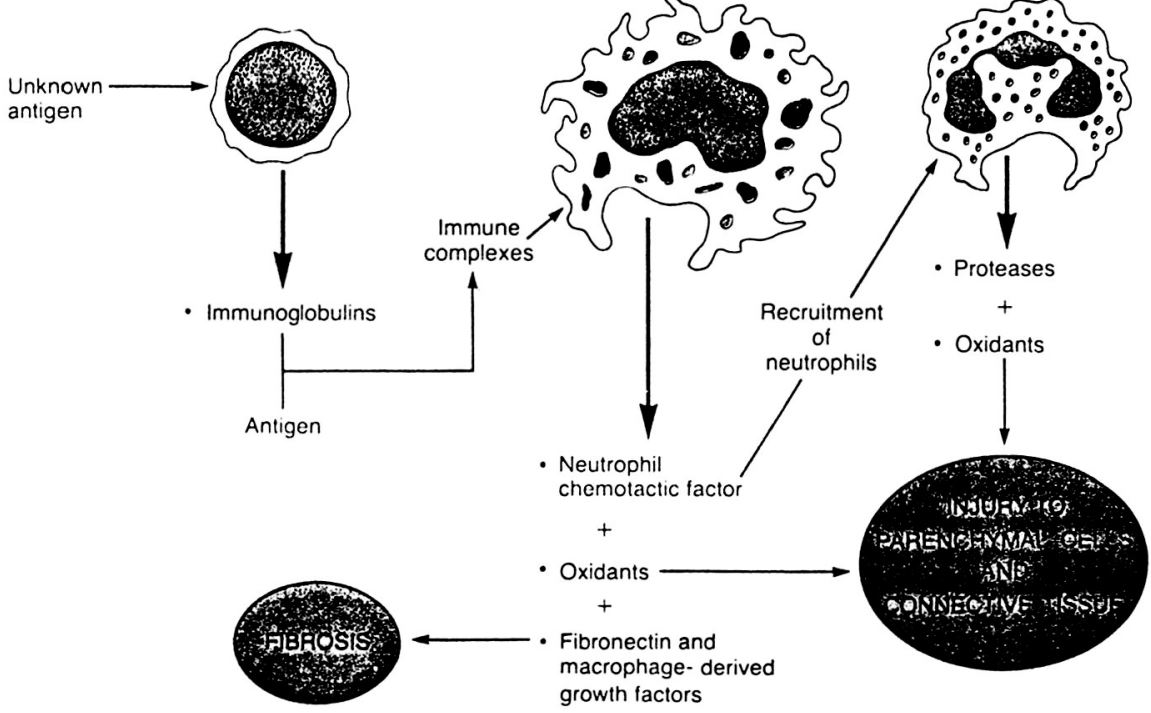

Fig. 2. Current concepts of the pathogenesis of idiopathic pulmonary fibrosis, in which immune complexes to some undetermined antigen may be the initial trigger to macrophage and neutrophil accumulation and activition. In other conditions, T cellmediated reactions may predominate. The end result is lung damage and fibrosis. (Adopted from Robbins Pathologic Bases of Disease, 4th Edit. 1989)

\section{특발성 간질성 폐 섬유증식증}

\section{1. 형태학적 변화의 진전}

$\mathrm{IDF}$ 는 한 특이한 임상적 질병 단위로 취급되고 있지 만, 이것을 다루고 있는 문헌들이 흔히 혼동을 일으키고 있다. 그 이유는 연구자들 사이에서 이 질병을 서로 다 른 이름으로 부르고 있기 때문이다. 영국에서는 동일한 질명을 특발성 섬유화성 폐포염 (cryptogenic fibrosing alveolitis) 으로 부르고 있다. 더욱더, IDF의 많은 소견 이 교원-혈관성 질환(collagen-vascular disease)에 동반된 간질성 폐 질환의 소견과 유사하기 때문에 양 질 환군을 혼동하고 있으나 대다수의 임상가들은 교원-혈 관성군으로부터 IDF를 분리 취급하고 있다. IDF를 혼 동하는 또다른 이유로 Liebow와 Carrington에 의하여 기술된 DIP와 UIP를 포함한 간질성 폐렴의 형태학적 분류와의 관계때문이다. 비록 IDF 환자의 폐 생검조직 이 DIP, UIP 또는 이 양쪽의 특징적인 소견과 동일하다 고 할지라도, 이러한 형태학적 변화는 특이성이 없고, 원인이 상이한 다른 간질성 폐 질환에서도 관찰된다. 그
래서 생검조직의 소견이 예후의 판정에는 중요할 수 있 을지라도 UIP와 DIP라는 형태학적 용어를 임상적으로 특이한 IDF란 용어와 서로 바꾸어 사용할 수는 없다.

$\mathrm{IDF}$ 는 진행성인 경과를 취하고 보통 초발 증상후 평 균 3 6년 사이에 사망한다. 폐 기능 검사는 폐 활량과 확산능의 감소를 보인다. 확산 능력의 감소는 폐포 모세 혈관 총의 소실을 반영하는 것으로 생각된다.

이 질환의 조기에는 제 I 형 $\mathrm{Pn}$ 의 괴사, 폐포강내 초 자막 형성, 섬유소 침착, 염증세포의 유출 및 제 II 형 $\mathrm{Pn}$ 의 증식을 특징으로 하는 미만성 폐포손상 $(\mathrm{DAD})$ 의 형태로 시작한다. 이 시기에는 환자가 별 증상을 호소하 지 않고, 폐기능의 장애가 별로 없기 때문에 폐 조직의 생검 대상이 되지 않는다. 그러나 폐장의 방사선소견은 매우 특징적이여서 갈은 유리(젖빛유리, ground-glass) 모양으로 보인다. 이때 Mallory 소체가 $\mathrm{Pn}$ 의 세포질내 에 출현할 수 있고, 폐포 내강에 청색소체가 관찰되기도 한다.

이 질환이 어느정도 진행하면, 폐포벽이 비후되고 여 기 저기에 폐포염의 소견이 관찰된다. 염증이 지속되고, 폡. 구조의 파괴가 계속된다. 제 I 형 $\mathrm{Pn}$ 의 괴사 소실, 


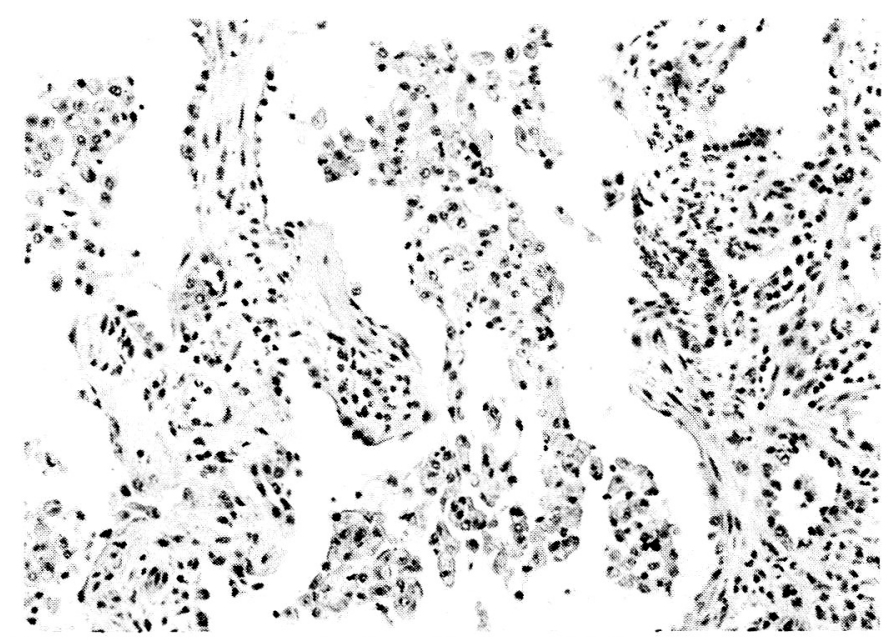

Fig. 3. Early phase of idiopathic interstitial pulmonary fibrosis. Inflammatory cells are centered in the interstitium of the lung accompanied by little fibrosis. The histologic features are those of DIP by Liebow (H-E stain, X200).

폐포 강내 $\mathrm{Ma}$ 의 유입, 제 II형 $\mathrm{Pn}$ 의 증식, 폐포강내 세 기관지 상피세포의 이주, 폐포 모세혈관의 소실 그리고 소 호흡기도와 동맥벽의 비후등이 나타난다. 이 시기를 폐포염의 세포성 병기(cellular phase of alveolitis)라 고 한다. 이때 간질성 기질이 양적으로 증가하는데, 섬 유모세포와 평활근세포가 다수 출현한다. 평활근세포는 기관지 벽에서 기원한 것이 폐포벽까지 이주한 것으로 생각된다. 특히, 제 I 형 교원으로 형성된 섬유가 엉키 고 파괴된 덩어리로 관찰된다. 때로는 상피성 기저막이 파열된 곳을 통하여 증식한 섬유조직이 폐포강내로 튀어 나와서 폐포강을 폐쇄한다. 이 시기에 해당하는 폐장의 방사선학적 소견이 ground-glass 또는 망상(reticular) 음영으로 기술된다.

이 질환이 더욱 진행함에 따라 IDF의 형태학적 특징 이라고 할 수 있는 탈락성 간질성 폐렴 (desquamative interstitial pneumonia, DIP)의 전형적인 소견을 보인 다. 폐포강내에 $\mathrm{Ma}$ 가 충만되고, 그 사이에 탈락한 제 II 형 Pn이 혼재한다. 폐포벽에는 교원 섬유가 증식하 고, 소수의 염증세포(림프구, 형질세포, 호중구등)와 부 종에 의하여 폐포벽이 넓어진다. 폐포 내강을 덮고 있는 제 II형 $\mathrm{Pn}$ 은 심히 증식한다. 제 II형 $\mathrm{Pn}$ 은 풍부한 세 포질을 가지며, 원형내지 타원형으로 폐포강내로 돌출 하고 있다(Fig. 3).

세기관지 폐포세척(BAL) 소견은 폐포염의 특징적인
양상을 보이는데, 작동세포의 정상 비율이 변하여 호중 구와 $\mathrm{Ma}$ 가 주종을 이루게 되고, 소수의 호산구와 림프 구가 관여한다. 출현하는 각종 작동세포의 구성 비율의 변화뿐만 아니라, 염증세포의 절대수가 몇 갑절로 증가 하게 된다. 다른 종류의 작동세포들도 숫적으로 증가하 게 된다.

Gallium-67 주사는 IDF 환자의 약 $70 \%$ 에서 양성으 로 나타난다. 그 양상은 보통 미만성이고, 폐 실질에 국 한된다. 염증세포들중 $\mathrm{Ma}$ 가 주로 표지원소(tracer)를 섭취하고, 호중구가 소량을 탐식하는 것으로 생각된다.

염증성 과정이 더욱 진행함에 따라 폐포강내 $\mathrm{Ma}$ 와 제 $\mathrm{II}$ 형 $\mathrm{Pn}$ 들이 점점 살아지고, 폐포강은 폐포벽의 섬유성 팽창으로 인하여 폐쇄된다. 폐포벽에도 염증세포가 소 실되고, 교원섬유가 심히 증식하면서, 평할근의 증식을 동반한다. 이런 변화를 Liebow는 상투성 간질성 폐렴 (usual interstitial pneumonia, UIP)이라고 불렀다 (Fig. 4). Scadding과 Hinson는 이 시기를 폐포염의 벽성 병기 (mural phase) 라고 불렀다. 폐포벽의 교원 섬 유의 증식을 특징으로 하는 시기로서 세포성 병기에 속 발하는 비교적 말기 변화이다. 방사선학적 변화는 주로 미세한 망상 또는 결절상(reticulonodular) 음영으로 관 찰된다.

전자 현미경적 검사에서 폐포벽의 섬유화 과정은 $\mathrm{Pn}$ 과 기저막의 결손 부위를 뜷고 활성화된 간엽성 세포가 


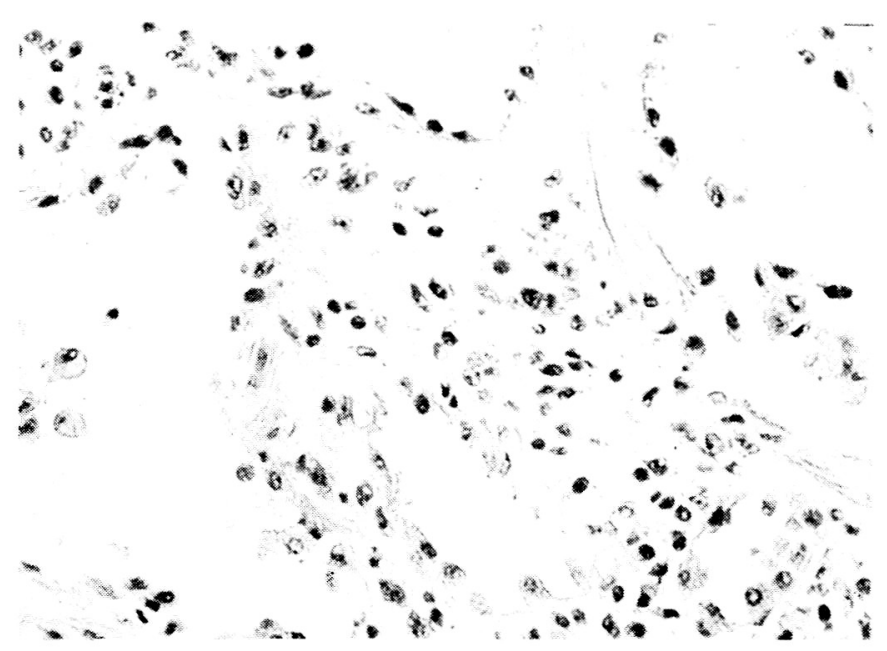

Fig. 4. Late phase of idiopathic interstitial fibrosis. There is extensive deposition of collagen in the alveolar septa leading to progressive obliteration of air spaces. The prominent Type II pneumocytes line the alveolar lumens ( $\mathrm{H}-\mathrm{E}$ stain, $\mathrm{X} 200)$.

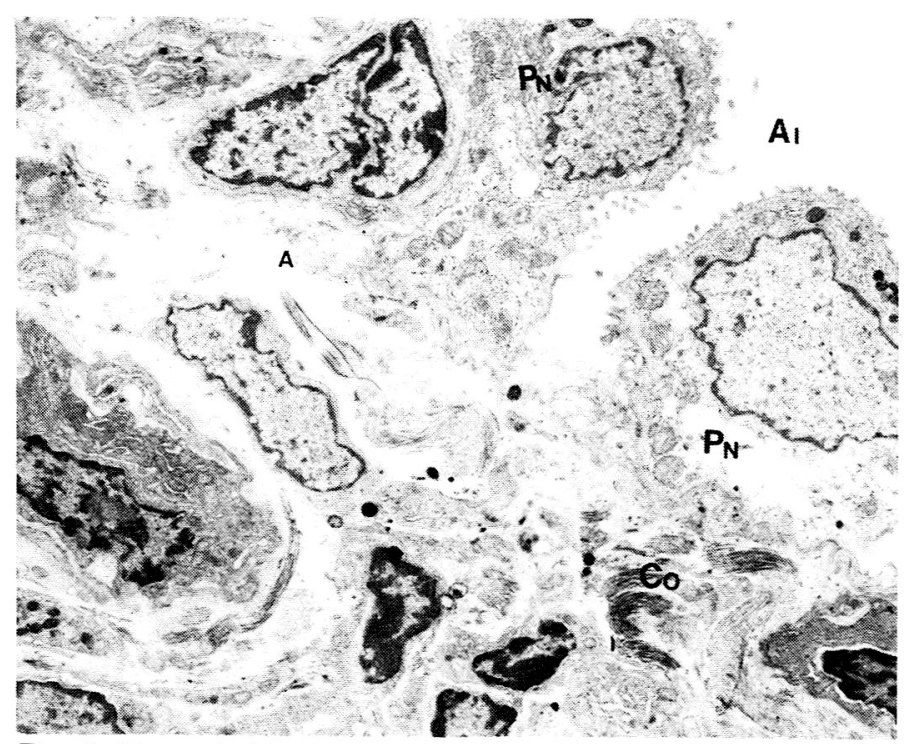

Fig. 5. Transmission electron microscopic feature of interstitial pulmonary fibrosis in a 6 year old girl. Type II pneumocytes (Pn) have cytoplasmic projections with microvilli into alveolar lumens (A1). The alveolar septum contains masses of collagen fibrils (Co). The epithelial basement membrane has been lost in areas (TEM, X3,500).

폐포벽으로부터 폐포강내로 이주함으로써 발생한다. 또 한 폐포강내 염증성 삼출액의 기질화에 따른 폐포벽의 영구적인 협착이 섬유화에 기여하는 또 다른 변화이다
(Fig. 5).

이 질환의 말기에는 교원섬유가 불규칙하게 증식하 고, 평활근의 증식 (근육성 경화증, muscular cirrhosis 
of the lung), 그리고 미세한 낭성 변화등이 관찰된다. 낭성구조들은 남아있는 $\mathrm{TB}$ 가 증식한 성유조직의 견인 에 의하여 확장됨으로서 발생한다. 이런 변화를 벌집 폐 장(honeycomb lung)이란 육아적인 서술적 용어로 기 술하여 왔다. 폐장의 다공성 변화는 국소적일 수도 있 고, 미만성으로 나타날 수도 있다. 이 변화는 모든 간질 성 폐 질환의 말기 현상으로(end stage lung disease) 폐기능은 심히 악화되고, 폐포-모세혈관 차단에 의한 산소 확산 능력이 격감되며, 환자는 저산소증으로 호흡 곤란이 격심하게 된다.

과거 이런 상태에 세기관지성 폐기종(bronchiolar emphysema)이란 부적합한 용어를 사용한 적이 있었으 나, 이의 본태는 세기관지 확장증(bronchiolectasis)이 지 폐기종이 아니다. 여기에서 폐포 또는 기관지 상피세 포의 편평화성 (squamous metaplasia)이 잘 발생하고, 나아가서 이들의 비전형성 증식, 종국에는 반흔 암(scar cancer)이 속발할 수 있다. 대다수의 반흔암은 조직학적 으로 선암종이지만, 드물게 편평세포 암종과 다른 종류 의 암종일 수도 있다.

\section{2. 발병기전}

$\mathrm{IDF}$ 의 원인은 불명이다. 그러나 폐포염이 이 질환의 가장 근본적이고 조기 변화인 증거는 확실하다. 이 질병 의 초기에 실시한 생검 표본에서는 폐포벽에 현저한 염 증과 경한 파괴현상이 관찰되지만, 질병의 중간기나 말 기에 실시한 생검 표본에서는 염증이 경하게 되고 폐포 구조의 파괴가 현저하게 나타난다. 더욱더, 폐포염의 강 도와 지속기간으로 환자를 나누어 생각해 볼때 장기간에 걸친 중증의 폐포염은 폐기능의 현저한 장애를 초래하는 반면 단기간의 경한 폐포염은 심한 장애를 유발하지 아 니한다. 끝으로, $\mathrm{BAL}$ 검사에서 가족성 $\mathrm{IDF}$ 환자의 가족 중 소아가 비록 폐 질환의 증상은 없음에도 불구하고, 경 한 폐포염의 소견을 나타낸다.

따라서 IDF는 폐포에 가하여지는 손상에 속발하는 조 직 반응을 억제하지 못하는 개체에 발생하는 한 염증성 과정이라고 할 수 있다. 이 개념에 부합되는 소견으로 이 질환을 가진 환자의 $\mathrm{T}$ 세포들은 제 I 형 교원과 $\mathrm{DNA}$ 를 포함하는 여러 종류의 “자가" 성분에 대하여 민감하게 증식한다. 바이러스 원인이 고려되고 왔지만, 바이러스 감염의 혈청학적 또는 형태학적 감염의 증거는 아직 찾 지 못하고 있다.
IDF의 드문 경우는 가족적인 발생 양상을 나타내기 때문에 유전적 소인을 암시하고 있다. 약 $30 \%$ 의 $\mathrm{IDF}$ 환 자의 말초 혈액내에서 순환하는 항 핵성 항체 (antinuclear antibody) 가 검출된다. 폐 조직의 면역 현광 검사에서 면역 globulin과 $\mathrm{C}_{3}$ 의 침착이 발견되고, 순환 혈액내 면역 복합체의 존재가 많은 증예에서 증명 된다. 이러한 사실은 IDF의 어떤 경우는 면역 복합체성 폐 질환임을 반영하는 것으로 해석된다.

\section{폐포염의 진단}

$\mathrm{IDF}$ 는 폐포염으로 시작하고 이 폐포염이 결국 폐장의 구조적 및 기능적 장애를 초래한다. 폐포염을 객관적으 로 판정하는데는 대체로 3 가지의 임상 수기가 이용되고 있는데, 개훙 폐 생검, 세기관지 폐포 세척 그리고 gallium-67주사이다.

\section{1. 개훙 폐 생검}

1960 년대 초부터 보편화된 개훙에 의한 폐장의 생검은 $\mathrm{IDF}$ 를 평가하는데 가장 직접적인 방법으로 인정받게 되 었다.

광학 및 전자 현미경적 검사와 더불어 면역 현광 검사 와 면역조직 화학적 검사등으로 조직내에 존재하는 면역 복합체를 직접 증명하는데 이용되고, 특이한 작동(주 효) 세포를 구별하는데 도움이 되는 세포 표면 항원을 검 색할 수도 있다. 더욱더 생검 조직에서 기계적으로나 효 소적 방법으로 작동세포를 분리하여 그들의 수, 종류 및 기능을 정성적으로 판정할 수 있게 된다.

\section{2. 세기관지 폐포 세척}

1970년대 초반에 개발된 BAL 수기로 LRA의 상피 표 면을 덮고 있는 액체와 폐포염에 관여하는 작동세포들을 반복 채취할 수 있게 되었다. 보통 세척 부위는 우 중엽 의 제 3 내지 제 4 분지의 기관지가 선택되지만, 기관지 경이 도달할 수 있는 어떠한 부위도 세척이 가능하다. 기 관지에 정확하게 도달하면 무균성 등장 식염수를 주입하 는데 $20 \mathrm{ml}$ 씩 5 번에 걸쳐 주입하고, 매 주입후 즉시 홉 입한다. 이렇게 하여 총 $100 \mathrm{ml}$ 가 주입되면 40 60 ml가 다시 홉입된다. 이로 인한 합병증은 별로 심각하지 않 다.

비흡연 정상 성인에서는 세척액 $1 \mathrm{ml}$ 당 약 $100 \times 10^{3}$ 
$\sim 150 \times 10^{3}$ 의 작동세포가 채취되는데, IDF 환자에서는 작동세포의 수가 2 5배로 증가한다. 또한 폐포 상피 피 복액을 채취함으로써, 염증 과정에 관여하는 중재물을 동정할 수가 있다. 정상인에서 $100 \mathrm{ml}$ 의 세척액에서 약 $1 \mathrm{ml}$ 의 폐포 상피 피복액을 얻을 수 있다. 한번의 세척 으로 약 $10^{6}$ 의 폐포를 세척하게 됨으로 염증의 정도가 폐 포들마다 달라도, 폐포염을 적절하게 반영하여준다고 할 수 있다.

용이하고, 안전하고, 반복시술이 가능하기 때문에 $\mathrm{BAL}$ 은 LAR의 염증을 평가하는데 유익한 방법으로 인 정받고 있다.

\section{Gallium-67 주사}

이 방사능 동위 원소 측정법은 급만서 염증 부위를 찾 는데 이용된다. 간질성 폐 질환의 판정을 위하여 gallium-67 citrate을 정주하고, 48시간 후 환자를 주사 (scan) 하게 된다. 정상 폐장에는 gallium-67이 거의 축 적되지 아니한다. 활동성 폐포염 환자에서는 폐 실질내 에 동위 원소가 국소적으로나 미만성으로 축적하게 된 다. 주사 상태는 폐장의 침범 범위와 침착의 강도에 기 준하여 판정된다.

염증 부위에 gallium-67의 축적 기전은 잘 알려지고 있지 않다. 그러나 작동세포가 생체내에서 gallium-67 를 섭취하고, 대식세포가 시험관내에서 활성화 되었을 때에 표지원소를 다량 섭취하는 것으로 보아 gallium -67 scan은 폐 실질내 활성화된 염증세포의 밀도 특히, 활성화된 대식 세포의 수를 잘 반영하는 검사법이라고 할 수 있다.

\section{REFERENCES}

1) 이중달·홍은경 : 소아에 발생한 특발성 간질성 폐 섬 유증식증. 대한병리학회지, 1989 (인쇄중)
2) Basset F, Ferrans VJ, Soler P, et al: Intraluminal fibrosis in interstitial lung disorders. Am J Pathol 122:443-461, 1986

3) Carrington CB, Gaensler EA, Coutu RE, et al: Natural history and treated course of usual and desquamative interstitial pneumonia. N Engl J Med 298:801-809, 1978

4) Coalson JJ: The ultrastructure of human fibrosing alveolitis. Virch Arch Pathol Anat 395:187-199, 1982

5) Crystal RG: Alveolitis. The key to the intersititial lung disorders. Thorax 37:1-10, 1982

6) Crystal RG, Bitterman PB, Rennard SI, et al: Interstitial lung diseases of unknown cause. Disorders characterized by chronic inflammation of the lower respiratory tract. N Engl J Med 310:154-166, 1984

7) Crystal RG, Gadek JE, Ferrans VJ, et al: Interstitial lung diseases: Current concepts of pathogenesis, staging and therapy. Am J Med 70:542-568, 1981

8) Fraire AE, Greenbery SD: Carcinoma and diffuse interstitial fibrosis of lung. Cancer 31:1078-1086, 1973

9) Katzenstein AA: Pathogenesis of fibrosis in interstitial pneumonia. An electron microscopic study. Hum Pathol 16:1015-1024, 1985

10) Liebow AA, Steer A, Billingsley JG: Desquamative interstitial pneumonia. Am J Med 39:369-404, 1965

11) Mayer EC, Liebow AA: Relationship of interstitial pneumonia honeycombing and atypical epithelial proliferation to cancer of the lung. Cancer 18:322 $-351,1965$

12) Scadding JG, Hinson KFW: Diffuse fibrosing alveolitis (diffuse interstitial fibrosis of the lungs). Correlation of histolygy at biopsy with prognosis. Thorax 22:291-304, 1967

13) Schatz M, Patterson R, Fink J: Immunologic lung disease. N Engl J Med 300:1310-1320, 1979

14) Tubbs RR, Benjamin SP, Reich NE, et al: Desquamative interstitial pneumonitis. Cellular phase of fibrosing alveolitis. Chest 72:159-165, 1977 